\title{
Fraud and Forensic Accounting: Knowledge and Risk Assessment Task Performance in Malaysian Public Sector - Conceptual study
}

\author{
Oluwatoyin Muse Johnson Popoola \\ School of Accountancy, College of Business \\ Universiti Utara Malaysia \\ Sintok, 06010 Darul Aman, Kedah, Malaysia \\ omjp0658@gmail.com
}

\author{
Ayoib Che Ahmad, PhD \\ School of Accountancy, College of Business \\ Universiti Utara Malaysia \\ Sintok, 06010 Darul Aman, Kedah, Malaysia \\ ayoib@uum.edu.my
}

\author{
Rose Shamsiah Samsudin, $\mathrm{PhD}$ \\ School of Accountancy, College of Business \\ Universiti Utara Malaysia \\ Sintok, 06010 Darul Aman, Kedah, Malaysia \\ shamsiah@uum.edu.my
}

\begin{abstract}
The PwC's 2011 Global economic crime survey confirms the fact that loss due to economic crime in Malaysia is on the increase and requires immediate intervention. The Malaysian government vision 2020 to be a developed nation with the drive: "People first, performance now" [1] will require high level acquisition and adoption of technology as a business facilitator, new legislation, and increase in the activities of government offer new opportunities for fraud perpetrators and forensic accountants. In anticipation of these challenges, this paper discusses the need for a forensic accountant knowledge on task performance fraud risk assessment in the Malaysian public sector. It also creates awareness to stakeholders fighting fraud in the public sector to the understanding of fraud mechanism and how to deal with fraudsters. The objective of the study is to examine the relationship between knowledge and fraud risk assessment task performance in the office of the Accountant general and Auditor general of Malaysia which has the potential to usher in the best global practices in fighting fraud in the Malaysian public sector.
\end{abstract}

Keywords - Forensic Accounting; Fraud; Fraud Risk Assessment; Knowledge; Public Sector; Malaysia.

\section{INTRODUCTION}

As a result of the much publicised PricewaterhouseCoopers International Limited's (PwC) 2011 Global Economic Crime Survey, which confirm that economic crime in Malaysia continues to be on the increase. The emphasis here is on theft and asset misappropriation as the most common type of economic crime that came to the limelight, followed by bribery and corruption, and accounting fraud [2]. In addition, the objective of the Malaysian government is to shift focus from developing nation to developed nation by 2020 with the drive:
"People first, performance now", and to be ranked within the first ten nations in the world characterised with a high level acquisition and adoption of technology as a business facilitator, complex legislation, and increase in government activities offer new opportunities for the perpetrators of fraud and high demand for forensic accountants.

As noted by the Committee of Sponsoring organisations of the Treadway commission (COSO), the obligation of the management in any public sector organisation which faces both external and internal risks is to put in place proper measures of control to reinforce its activities and adopt the best strategy to detecting, preventing and responding to the monster called "fraud" [3].

According to [4], the Executive Director of $\mathrm{PwC}$ in Malaysia, fraud against governments or state owned enterprises increased by $29 \%$ in comparison with 2009 figure (i.e. the $44 \%$ reported in the 2011 survey represents a $57 \%$ increase over the $28 \%$ reported in the 2009 survey), thus leaping upward of the hospitality and leisure and financial services sectors as a target for crime [4]. Similarly, the red flags emanating from the Auditor general's 2011 audit report on the government financial statement alleging the overspending of allocated budgets and public officials indulge in wasteful spending [5] confirms the concern of the study.

As a result of the huge loss due to fraud in the public sector environment which has a direct impact on the development of infrastructure, facilities, utilities, and building the public trust, it is necessary for those in authority in any government ministry, department and agency to design 
procedures primarily meant to detect and prevent fraud from internal and external activities which may be difficult for any fraud perpetrator to penetrate since fraud can come in a variety of ways, shades and forms. With this development and for the purpose of accountability and transparency for good governance, this study intends to examine the task performance fraud risk assessment and forensic accounting knowledge and auditing knowledge of accountants and auditors in the Malaysian public sector.

Since no government at any level is immune from the influence of fraud, it is very important for reforms in the capability and competence of those responsible for accounting matters and procedures relating to federal and state government accounts, the preparation and presentation of government financial statement, registrar of unclaimed moneys (Unclaimed Money Act, 1965) [6], head of service for accountants at all cadres on one hand and those responsible for the unbiased examination and evaluation of the financial statements as well as the "systems and processes" responsible for recording and summarising that information, head of auditors at all cadres, on the other hand [7], [1], [8] and [9].

The shift from accounting and auditing [10] and [11] to forensic accounting or public accountabilities offers accountants and auditors the chance to pull themselves out from their somewhat dull, and bookkeeping background, thus enhancing their public legitimacy through taking up of forensic accounting specialized knowledge [12], [13] and [14].

According to previous studies, the change to public accountability will put accountants and auditors more in the political spotlights, which symbolises the manner to account for themselves, for the standards adopted and applied, for the sophistication and independence of their judgement at the risk of decreased legitimacy [15], [16] and [17].

The question that comes to mind in Latin is "quis custodiet ipsos custodies?", that is, "who audits the accountants and auditors themselves?"

Forensic accountants came into existence as essential associates in the fight against fraud and economic crimes. Forensic accountants with appropriate education, training, and experience can provide additional assistance to other agencies and departments charged with the responsibility of enforcement, regulation and recovery, audit committees and financial statement audit teams to enhance their functions and duties [7].

The forensic accountants' significance will have a positive effect in building and restoring public trust through the tools of transparency and accountability in the Malaysian public sector especially and in general, the country at large.

Based on the challenges occasioned by fraud, the need for reforms and the establishment of various institutional, legal and regulatory frameworks cannot be over-emphasised in the Malaysian public sector. The American institute of certified public accountants issued the statement on auditing standards (SAS) No. 99 which deals with the consideration of fraud in a financial statement audit [18]. In addition, the Institute of chartered accountants of Nigeria (ICAN) issued Nigerian standards on auditing (NSA) No 5, the auditor's responsibility to consider fraud in an audit of financial statements [19] and the Malaysian institute of accountants issued international standards on auditing (ISA) No. 240, the auditor's responsibilities relating to fraud in an audit of financial statements [20]. These standards seek to address issues relating to fraud that provoke public outcry on the financial statement auditors' ability and responsibility for fraud detection, prevention and response. One of the suggestions for consideration in SAS 99 and ISA 240 regarding the overall responses to the risk of material misstatement due to fraud is the assignment of personnel and supervision. Section 29 (a) ISA 240 (MIA, 29a, para. A34, 2008) and Section 50 of SAS No. 99 identify"the auditor may respond to an identified risk of material misstatement due to fraud by assigning additional persons with specialised skill and knowledge, such as forensic and information technology (IT) experts or specialists" [21], [22], and [18].

In Malaysia, the organ of accountability and transparency is Malaysian anti-corruption commission (MACC). This agency has wide powers to enforce all applicable laws to arraign, prosecute, and confiscate on behalf of the government from any perpetrators of fraud, economic and white collar crimes [23].

Notwithstanding all these measures, loss due to fraud in the public sector is on the increase. For instance, the 2011 National Fraud Authority, Annual Fraud Indicator (NFAAF) in the United States reported a loss traced to the public sector of $\$ 21.2$ billion (55\% of the total loss) out of $\$ 38.4$ billion. Other areas include private sector $\$ 12$ billion, individual $\$ 4$ billion and charitable organization $\$ 1.2$ [24]. Even though, there is no statistical database in Malaysia to ascertain and evaluate the level of fraud in the public sector, yet the researcher argues that a fraud has become endemic, a cankerworm which defies all prescriptions as buttressed by the PwC survey [2] and the Auditor general 2011 audit report [25] on the government financial statements.

For example, the following few cases were reported: alleged three-billion ringgit cost overrun on a rail project in northern Malaysia; alleged government departments spending much over the going rate for items including torch lights and billboards; alleged customs official shopping spree spending of more than one million ringgit without authorisation; alleged and unconfirmed government spending of over three million ringgit to set up just six billboards in Indonesia; alleged opening cost of Malaysian venture restaurants in London and Tokyo that collapsed but costing the government RM14 million; alleged diversion of RM240 million loan by the 
government for cattle-rearing business to acquisition of high end condominiums and expensive holidays [5] and [25]. More cases of fraud and economic crimes can be found in the Malaysian various organs of accountability websites.

\section{LITERATURE REVIEW}

\section{A. Public Sector}

The term "public sector" denotes all organisations which are owned and operated, not by private settings, but are established, operated and funded by the government at all levels (federal government, state government, federal statutory bodies, state statutory bodies, local government, town, district councils and city halls, and an Islamic Council of Malaysia) on behalf of the public [26], [1], [27] and [28].

\section{B. Concept of Auditing}

Auditing is defined as an unbiased examination and evaluation of the financial statement of any organisation with a view to express an opinion on its truth and fairness in accordance with International financial reporting standards, International public sector accounting standards and International standards on auditing [29], and [30], International standards on quality control and any applicable international, national or local equivalents. There are two distinct ways by which auditing can be carried out in any organisation. These are (1) internal (by employees of the organisation usually called internal auditor) and (2) external (by an independent professional firm, sometimes called a statutory independent auditor).

Similarly, the International standards on auditing [31] No. 700 provide "the objective of the audit of financial statements is to enable the auditor to express an opinion whether the financial statements are prepared, in all material respects, in accordance with the applicable financial reporting framework. Hence, an audit of financial statements is an assurance engagement as defined in the International framework for assurance engagement [32]. Auditing services, on the other hand, involve evaluating the reliability and credibility of financial information, as well as "the systems and processes responsible for recording and summarising that information in accordance with international and local standards of auditing, judicial pronouncements and other relevant statutes" [9].

\section{Concept of Forensic}

According to Merriam Webster Dictionary, the word "forensic" means "belonging to, used in or suitable to courts of judicature or to public discussion and debate". In essence, any information or document which may be suitably used in courts of law or public discussion is regarded as "forensic information or forensic document".

\section{Concept of Forensic Accounting}

According to [33] and [7], forensic accounting is defined as the integration of specialised accounting knowledge and enhanced skills to solve complex financial issues in any court of law or public domain. As noted by [34], forensic accountants will continue to exist for the same reasons as fraud and economic crimes perpetrators, prosecutors and commercial branch investigators exist. This assertion may possibly be traceable to the occurrence and likelihood of criminals in the areas of fraud, white collar crimes, corruption, money laundering, computer fraud, and asset misappropriations.

The American institute of certified public accountants defines forensic accounting as "the ability to identify, collect, analyse, and interpret financial and accounting data and information; apply the relevant data and information to a legal dispute or issue; and render an opinion" [18]. Reference [35] agrees with AICPA definition and buttresses that forensic accounting is not "accounting for dead people", rather it is the use of a wide range of accounting, auditing, and investigative skills to measure and verify economic damages and resolve financial disputes.

\section{E. Concept of Transparency and Accountability}

Reference [36] defines accountability as the ability to give explanations or reasons regarding what one does at any given time; it is about the ability to satisfactorily account for whatever has been entrusted to one's care. According to [37], accountability can be looked at as the obligation to respond for a responsibility already conferred in whatever means. The previous study describes public accountability as the obligation of an actor to openly clarify and justify behaviour to any significant level [15] and [38].

As noted by [15], accountability is more of a complex notion which implies an accurate and proper rendering of accounts and comprises both fiscal accountability and process accountability. To elaborate further, fiscal accountability refers to the confirmed demonstration that the organisation has achieved its intended objectives while process accountability, which confirms that the ministry, department and agency has acted in accordance with its mission statement.

The concept of transparency, on the other hand, entails the dissemination of information that the public has a legal right to access at any given moment [15]. This involves genuine communication policy which includes the publication of detailed reports that set out the organization's financial position and financial management principles and disclose internal decision making structures, operational methodologies and details of continuing and proposed projects and initiatives [38]. 


\section{F. Concept of Fraud}

The term "fraud" comprises activities occasioned by theft, corruption, conspiracy, embezzlement, money laundering, bribery and extortion and the legal definition varies from country to country save for the Fraud Act (2006) that produces its legal definition in England and Wales [39]. Fraud fundamentally involves using deceptive means to falsely make a personal gain for oneself and/or create a loss for another. Scholars definitions of fraud vary, but most are based around these general themes [39]. For instance, the Black's Law Dictionary defines fraud as all multifarious means which human ingenuity can devise, and which are resorted to by one individual to get an advantage over another by false suggestions or suppression of the truth. It includes all surprise, trick, cunning or dissembling, and unfair way by which another is cheated [40].

With reference to the Association of Certified Fraud Examiners [41], three main types of fraud affect organisations. The category of fraud is as follows: (1) asset misappropriations - theft or misuse of organisation's asset (theft of plant, inventory or cash, false invoicing, accounts receivable fraud and payroll fraud); (2) fraudulent statements - falsification of financial statements (falsifying documents such as employee credentials); and (3) corruption - bribes or acceptance of kickbacks, improper use of confidential information, conflicts of interest and collusive tendering. The Chartered Institute of Management Accountants [39] agrees with [41] on the influence of these types of fraud in organisational settings. Figure 2.1 summarises the internal fraud in any organisation.

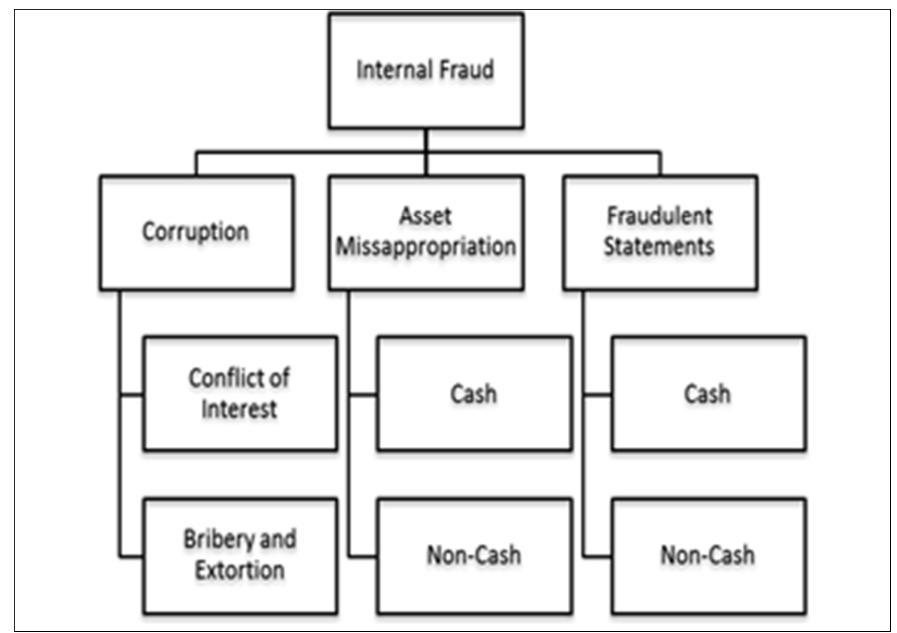

Figure 2.1: Types of Internal FraudAdapted: Chartered Institute of Management Accountants (CIMA, 2008)

\section{CONCEPTUAL FRAMEWORK}

\section{A. Task Performance Fraud Risk Assessment (TPFRA)}

Task performance fraud risk assessment (TPFRA) is the subject of this study because every ministry, department, and agency of government is not immune to a variety of risks from both external and internal sources. In addition, TPFRA helps auditors determine the organisational environment and the extent of audit procedures that have the possibility to increase the prospect of revealing fraud [42], [34], and [43].

Fraud risk assessment identifies and explains the process and procedure of the audit. It involves an iterative process for identifying and assessing risks to the attainment of organisational objectives [3]. The financial statement auditor is expected to design relevant and appropriate audit procedures that will assess the risk of material misstatement due to fraud or error. The management is required to consider the effect of a change in its external and internal environment which may impair on the effectiveness of the internal control established in the organisation. In achieving the organisation's objective, five components of internal control were identified as significant to potential and actual fraud in any government establishment [3]. These components include control environment, control activities, risk assessment, monitoring activities and information and communication [3].

As noted by [44] and [19], the Auditor's procedures in response to assessed risk, and the [21], the Auditor's response to assessed risk, it is the responsibility of the auditors to select appropriate procedures based on the auditor's judgment, including the assessment of the risks of material misstatement of the financial statements, whether due to fraud or error. In making those risk assessments, the auditor considers internal control relevant to the entity's preparation and fair presentation of the financial statements in order to design audit procedures that are appropriate in the circumstances, but not for the purpose of expressing an opinion on the effectiveness of the entity's internal control [44], [21], [45], and [19].

Similarly, Statement of auditing standards (SAS) No. 82: Consideration of fraud in a financial statement audit [46], requires documentation of fraud risk by the auditor during the planning stage of the audit and to update the initial assessment as obligatory throughout the course of the engagement. SAS No. 99 discusses relevant fraud risk factors that might indicate the presence of an intentional material misstatement, that is, fraud [18]. The fraud risk factors identified are incentive/pressure, opportunity, and attitude/rationalization [18], [48], and [47]. In essence, fraud risk assessment has a direct relationship on the effectiveness of forensic accountants and auditors' fraud detection in an audit.

Based on the different shades of argument, this study focuses on fraud risk assessment [42] relevant to the public sector environment under consideration [7].

B. Forensic Accountant Knowledge and Auditor Knowledge

Fraud detection, prevention and response denote an integral part of the specialised knowledge of forensic 
accounting as a field in the accountancy profession whose objectives include: credibility, quality of service, professionalism, and confidence [16], and [49]. Other services of forensic accounting include computer forensic analysis, family law, valuation, financial statement misrepresentation, economic damages calculations, and bankruptcy, insolvency and reorganisation [12], [13], and [14].

Prior studies are in agreement that persons who are resourceful in the application of information technology, legal, investigative, criminology, psychology and accounting will perform better in the areas of accounting records, gathering and evaluating financial statement evidence, interviewing all parties related to an alleged fraud situation, and serving as an expert witness in a fraud case [50], [51], and [52].

Whereas, auditor's knowledge comprises historical financial information audit at a higher level, financial accounting and reporting at a higher level, and information technology [53]. Similarly, auditor's knowledge is limited to the specific organisation environment and scope of the audit assignment. This study notes that the impression of standard setters merely requiring auditors as per various standards on the "Consideration of fraud in an audit of financial statements [21], [19], and [18] to be aware of the probability of fraud in a financial statement audit [50] and [19] is not enough to detect fraud as argued by Association of certified fraud examiners [54] and [55], and this assertion based on extant literature review is also supported by this study.

The need for a forensic accountant is awakened because of the disappointment of audit system in the organisation as the organisational internal and external audits were unsuccessful to figure errors in the managerial system [56]. Reference [57] indicates that other accountants may look at the charts, but forensic accountants actually dig deep into the body. For this study, the researcher agrees to the fact that fraud investigation is not a child's play, and it requires a lot more than knowledge of historical financial information audit at a higher level, financial accounting and reporting at a higher level, and information technology [32].

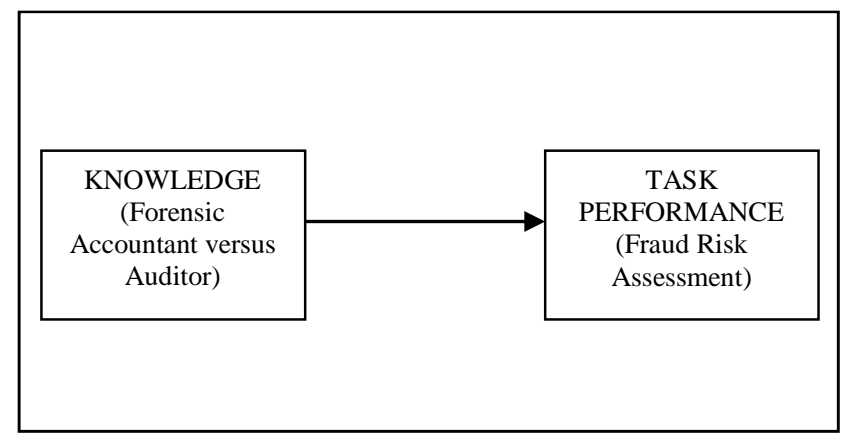

Figure 3.1 Conceptual framework of task performance fraud risk assessment of knowledge (forensic accountant and auditor)
Specifically, as a result of the increase in fraud and corruption, trade globalisation, new and complicated legislation, controversial environment, and growth in the use of, and sophistication of technology as a business facilitator, forensic accounting services will continue to be in hot demand in years to come [58], [13], and [59].

Figure 3.1 above summarises earlier literature and illustrates the conceptual framework of task performance fraud risk assessment of knowledge (forensic accountant and auditor) in the Malaysian public sector. The assessment of fraud risks by applying the forensic accountant knowledge may have a tendency to stimulate higher task performance than the auditor knowledge in the public sector environment.

\section{CONCLUSION}

This paper discusses the forensic accountant knowledge and auditor knowledge on task performance fraud risk assessment in the Malaysian public sector in adherence to the PcWs 2011 Global economic survey [2] on the continuous increase of economic crimes and PCAOB's [45] challenges on who has the capability to detect fraud to the accounting researchers. It also draws the attention of the users of public sector accountants and auditors such as the regulatory and enforcement agencies, courts, ministries, departments and agencies to the fact that understanding the mechanisms of fraud schemes and the ability to prevent, detect and respond to fraud require a holistic approach by adopting the forensic accounting knowledge in task performance fraud risk assessment.

\section{REFERENCES}

Selamah, W. S. (2011). Current status of public sector accounting in Malaysia and the way forward. The National Public Sector Accountants Conference (NAPSAC 2011). Transitioning to a new public sector accounting landscape, June. Jabatan Akauntan Negara Malaysia. (Accountant General of Malaysia).

PwC. (2011). PwC's 2011 Global Economic Crime Survey finds economic crime in Malaysia continues to increase. 6th Global Economic Crime Survey. Retrieved on February 14, 2013 and Downloaded from http://www.pwc.com/gx/en/economic-crimesurvey/index.jhtml.
COSO. (2011). Internal Control Framework: Committee of Sponsoring Organizations of the Treadway Commission. New York. NY.

Peen, L. S. (2011). "No industry or company in any country is immune from the impact of fraud". 6th Global Economic Crime Survey. Kuala Lumpur November 30, 2011. Retrieved on February 14,2013 at 2013 at http://www.pwc.com/my/en/press/111130global-economic-crime-survey.jhtml.

Santiago, C. (2012). Audit Report 2011: Nothing has changed. Retrieved on February 14, 2013 at http://www.freemalaysiatoday.com/category/opinion/2012/10/22/a udit-report-2011-nothing-has-changed/

UMA. (1965). Unclaimed Money Act. Malaysia. 
Popoola, O.M. J., Ahmad, A. C., Shamsiah, R. S., \& Hartini, A. (2013). Task Performance Fraud Risk Assessment on Forensic Accountant Knowledge and Mindset in Nigerian Public Sector.

ICAN. (2009). The Institute of Chartered Accountants of Nigeria Public Sector Accounting Study Pack. VI Publishers, Lagos, Nigeria.

[9] Messier, W. F., Glover, S. M., \& Prawitt, D. F. (2006). Auditing \& Assurance Services: A Systematic Approach. Issues in Accounting Education, 21 (3), 330.

[10] FPA. (1957). Financial Procedures Act. (Revised 1972). Malaysia.

[11] AA. (1957). Audit Act. (Revised 1972). Malaysia.

[12] Durkin, R., \& Ueltzen, M. (2009). The Evolution of The CFF Credential, The Practicing CPA, July/August.

[13] Davis, C; Farrell, N., \& Ogilby, S. (2009). Characteristics and skills of the Forensic Accountant. American Institute of Certified Public Accountants FVS section.

[14] AICPA. (2008). Forensic and Valuation Services: Overview of Certified in Financial Forensics (CFF) Credential (American Institute of Certified Public Accountants, Durham. Retrieved September, 2009, from http://fvs.aicpa.org/Memberships/ Overview+of+Certified+in+Financial+Forensics+Credential. htm.

[15] Popoola, O.M.J. (2009). "Transparency, Accountability and Value for Money Audit". National Workshop on Global Meltdown, and Attitudinal Change. National Orientation Agency, Nigerian Institute of Policy \& Strategic Studies, Kuru, Jos, Nigeria.

[16] Popoola, O.M.J. (2008). Update on auditing and ethical standards. Executive Mandatory Continuing Professional Education, Institute of Chartered Accountants of Nigeria, Lagos, Nigeria.

[17] Pollitt, C., Gierre, X., Lonsdale, J., Mul, R., Summa, H., Waerness, M. (1999). Performance or Compliance?: Performance audit and public management in five countries. Oxford: OUP.

[18] AICPA. (2002). American Institute of Certified Public Accountants. Statement on Auditing Standards (SAS) No. 99, Consideration of Fraud in a Financial Statement Audit (AICPA, Professional Standards, vol. 1, AU Sec. 316.50

[19] ICAN. (2005). Nigerian Standards on Auditing (NSA) No. 5: The Auditor's responsibility to Consider fraud in an Audit of financial statements. Institute of Chartered Accountants of Nigeria (ICAN).

[20] MIA. (2008). International standard on Auditing No. 240, The Auditor's Responsibilities Relating to Fraud in an Audit of Financial Statements. Malaysian Institute of Accountants.

[21] MIA. (2008). International Standard on Auditing No. 330, The Auditor's Responses to Assessed Risks. Malaysian Institute of Accountants.

[22] ICAN. (2005). Nigerian Standards on Auditing (NSA) No. 11: Auditor's procedures in response to assessed risk. Institute of Chartered Accountants of Nigeria (ICAN).

MACC. (2009). Malaysian Anti-Corruption Commission Act. Malaysia
NFAAF. (2011). The National Fraud Action Agency for Fraud 2011, "Fighting fraud together: the strategic plan to reduce fraud". USA.

MGAR, (2011). Auditor General of Malaysia Audit Report. Kuala Lumpur, Malaysia

IFAC. (2012). International Public Sector Accounting Standard Board. Handbook of International Public Sector Accounting Pronouncements. 2012 Ed., Vol. 1 International Federation of Accountants

Hassan, M. M., (2001). Government Accounting, Lagos, Nigeria: Malthouse Press Limited.

FCM. (1972). Federal Constitution of Malaysia (Revised 1972). Malaysia.

Adebisi, F. A. (2011). Audit, Investigation and Forensics: Similarities and Differences. Institute of Chartered Accountants of Nigeria: Forensic, Audit \& Investigation Faculty, February.

IFAC. (2006). International Accounting Education Standard Board (IES 8, 2006). Competence Requirements for Audit Professionals. International Federation of Accountants.

FRC. (2012). International Standard on Auditing (ISA) No. 700: The auditor's report on financial statements.

IFAC. (2006). International Framework for Assurance Engagements. International Federation of Accountants.

Popoola, O.M. J., Ahmad, A. C., Shamsiah, R. S., \& Rushami, Z Y. (2013). Impact of Task Performance Fraud Risk Assessment on Forensic Skills and Mindsets: Experience from Nigeria

Wuerges, A. (2009). Auditors' Responsibility for Fraud Detection: New Wine in Old Bottles? Retrieved on November 3, 2012 at http://www.scribd.com/doc/63671899/Auditors-Responsibility-forFraud-Detection.

Boleigha, P. (2011). Meaning of Forensic. Institute of Chartered Accountants of Nigeria: Forensic Audit \& Investigation Faculty.

Dandago, K. I. (2001). Financial Accounting Simplified. $\left(2^{\text {nd }} E d\right.$, p. 143). Kano, Nigeria: Adamu Joji Publishers.

Onyeanu, E. O. (2005). Poor Growth of partnership among professionals in South Eastern Nigeria: A case for transparency and Accountability. Bayero International Journal of Accounting Research, Nov. 2005, vol. 2, no. 1 p.13-19.

Bovens, M. (2006). Analysing and assessing public accountability: A conceptual framework. European Governance Papers. (EUROGOV) No C-06-01. http://www.connex network.org/eurogov/pdf/egp-connex-C-06-01.pdf.

CIMA. (2008). Fraud Risk Management: A guide to good practice. Chartered Institute of Management Accountants.

Nolan, J. R., Nolan-Haley, J. M., Connolly, M. J., Hicks, S. C., \& Alibrandi, M. N. (1990) Black's Law Dictionary. 6th Ed. St Paul, Minn: West Publishing Co.

ACFE. (2008). Report to the Nation on Occupational Fraud and Abuse. Association of Certified Fraud Examiners. Austin, TX: ACFE. 
Chui, L. (2010). An experimental examination of the effects of fraud specialist and audit mindsets on fraud risk assessments and the development of fraud-related problem representation. ProQuest LLC, UMI 3436520, 789 East Eisenhower Parkway, USA, 2010.

[43] Bloomfield, R. J. (1997). Strategic Dependence and the Assessment of Fraud Risk: A Laboratory Study: The Accounting Review, Vol. 72, No. 4, 1997, p. 517-538

[44] IFAC. (2009). 'International Standard on Auditing (ISA) No. 240 Revised: The Auditor's Responsibility to Consider Fraud in an Audit of Financial Statements', Handbook of International Auditing, Assurance, and Ethics Pronouncements. International Federation of Accountants. New York.

[45] PCAOB. (2008). Public Company Accounting Oversight Board. Standing Advisory Group. Retrieved December 2, 2012 from http://www.pcaobus.org/Standards/Standing_Adisory_Group/index .aspx.

[46] AICPA. (1997). American Institute of Certified Public Accountants. Statement of Auditing Standards (SAS) No. 82: Consideration of fraud in a financial statement audit. Durham.

[47] Cressey, D. R. (1950). The criminal violation of financial trust. American Sociological Review 15 (6): 738-743.

[48] Cressey, D. R. (1953). Other People's Money: A Study in the Social Psychology of Embezzlement (The Free Press, Glencoe, Il)

[49] IFAC. (2008). Code of Ethics for Professional Accountants. International Federation of Accountants. New York. Retrieved at: https://www.ifac.org

[50] Hopwood, W. S., Leiner, J., \& Young, G. R. (2008). Forensic Accounting. New York, NY: McGraw-Hill/Irwin, http://www.acfe.com/about/press-release.asp?copy=10-12-2005.

[51] Rosen, L. S. (2006a). "CAP Forum on Forensic Accounting in the Post-Enron World Forensic Accounting: Where and When Headed?" Canadian Accounting Perspectives 5 (2): 257-264.
[52] Singleton, T. W., Singleton, A. J., Bologna, G. J. \& Lindquist. R. J. (2006). Fraud Auditing and Forensic Accounting. 3rd Ed. Hoboken, NJ: John Wiley and Sons, Inc.

[53] IFAC. (2006). International Education Standard No. 8, Competence requirements for professional accountants. International Accounting Education Standard Board. International Federation of Accountants.

[54] ACFE. (2010). Report to the Nations on Occupational Fraud and Abuse. Association of Certified Fraud Examiners. Austin, TX: ACFE.

[55] ACFE. (2009). Managing the Business Risk of Fraud: A Practical Guide, (sponsored by The Institute of Internal Auditors, The American Institute of Certified Public Accountants, and the Association of Certified Fraud Examiners). Pp.2-17. Retrieved on 19 October, 2012 at http://www.acfe.com/documents/managingbusiness-risk-pdf.

[56] Owojori, A. A., \& Asaolu, T. O. (2009). The role of forensic accounting in solving the vexed problem of the corporate world. European Journal of Scientific Research, 29 (2), 183-187.

Daniel, A. \& Lee B. (2006). Forensic Accountants appearing in the Literature. Retrieved March 10, 2012 at www.bus.lsu.edu/accounting/faculty/lcrumbley/forensic.html.

[58] Ekeigwe, C. C. (2011). Skill sets for Forensic Accountant. Institute of Chartered Accountants of Nigeria: Forensic Audit \& Investigation Faculty.

[59] Wells, J. T. (2005). Accountants need help fighting the war on fraud; ACFE founder urges antifraud education [Press Release]. Retrieved November 13, 2012 from ACFE http://wwwacfe.om/about/press-release.asp?cpy=10-12-2005. 